\title{
Laccase-Mediator Pretreatment of Wheat Straw Degrades Lignin and Improves Saccharification
}

Jorge Rencoret ${ }^{\mathrm{a} \ddagger}$, Antonio Pereira ${ }^{\mathrm{a} \ddagger}$, José C. del Río ${ }^{\mathrm{a}}$, Angel T. Martínez ${ }^{\mathrm{b}}$, Ana Gutiérrez $^{\mathrm{a}, *}$

${ }^{a}$ Instituto de Recursos Naturales y Agrobiología de Sevilla, CSIC, Reina Mercedes 10, E-41012 Seville, Spain

${ }^{\mathrm{b}}$ Centro de Investigaciones Biológicas, CSIC, Ramiro de Maeztu 9, E-28040 Madrid, Spain

\footnotetext{
* Corresponding author: Tel.: +34 954624711, Fax: +34 954624002, E-mail: anagu@irnase.csic.es (A. Gutiérrez)

$*$ These authors contributed equally to this work
} 
Abstract Agricultural by-products such as wheat straw are attractive feedstocks for the production of second generation bioethanol due to their high abundance. However, the presence of lignin in these lignocellulosic materials hinders the enzymatic hydrolysis of cellulose. The purpose of this work is to study the ability of a laccase-mediator system to remove lignin improving saccharification, as a pretreatment of wheat straw, and to analyze the chemical modifications produced in the remaining lignin moiety. Up to $48 \%$ lignin removal from ground wheat straw was attained by pretreatment with Pycnoporus cinnabarinus laccase and 1-hydroxybenzotriazole (HBT) as mediator, followed by alkaline peroxide extraction. The lignin removal directly correlated with increases $(\sim 60 \%)$ in glucose yields after enzymatic saccharification. The pretreatment using laccase alone (without mediator) removed up to $18 \%$ of lignin from wheat straw. Substantial lignin removal (37\%) was also produced when the enzyme-mediator pretreatment was not combined with the alkaline peroxide extraction. Two-dimensional nuclear magnetic resonance (2D NMR) analysis of the whole pretreated wheat straw material swollen in dimethylsulfoxide- $d_{6}$ revealed modifications of the lignin polymer, including the lower number of aliphatic side-chains involved in main $\beta-O-4^{\prime}$ and $\beta-5^{\prime}$ inter-unit linkages per aromatic lignin unit. Simultaneously, the removal of $p$ hydroxyphenyl, guaiacyl and syringyl lignin units and of $p$-coumaric and ferulic acids, as well as a moderate decrease of tricin units, was observed without a substantial change in the wood polysaccharide signals. Especially noteworthy was the formation of $\mathrm{C} \alpha-$ oxidized lignin units during the enzymatic treatment.

Keywords: Enzymatic delignification, Laccase-mediator, Lignin, wheat straw, 2D NMR, Bioethanol

\section{Introduction}

Agricultural and forestry residues represent an enormous source of readily available biomass for biofuel production without the need for additional land cultivation. Among agricultural residues, wheat straw is potentially one of the most favorable feedstocks in terms of the quantity of biomass available [1]. However, in spite of the availability of these residues or other lignocellulosic biomass, their variable composition and recalcitrance represent some technical and economic challenges. Cellulose, hemicelluloses and lignin are the three main components of lignocellulosic biomass linked into a complex matrix highly resistant to chemical and biological conversion. These components are more resistant to being broken down and fermented than starch and sucrose in the conventional food crops, making the conversion processes more complicated. Biofuel production from lignocellulosic material requires deconstruction of the cell-wall into individual polymers, and hydrolysis of the carbohydrates into monomeric sugars. One of the major factors causing biomass recalcitrance towards saccharification is correlated with the content and composition of lignin [2-4].

Lignin is a three-dimensional polymer constituted by phenylpropanoid subunits linked together by different ether and carbon-carbon bonds. Lignin is intimately interlaced with hemicelluloses in the plant cell wall forming a matrix to cover the largely crystalline cellulose microfibrils. Its aromatic nature and complex structure makes lignin degradation very difficult. Lignin has been shown to have a detrimental effect on the hydrolysis of biomass because it physically hinder the access of cellulases and also binds them reducing activity [5]. Therefore, biomass pretreatment to remove lignin is essential for the enzymatic hydrolysis of lignocellulose. Biotechnology can 
contribute to plant biomass deconstruction by providing biocatalysts being able to degrade or modify lignin [6]. Due to the complex structure of lignin, including heterogeneity of the monomers and linkages, which are not hydrolyzable, these biocatalysts must be oxidative (i.e., oxidoreductases) and also nonspecific. Among these, laccases seem to be the most suitable enzymes for industrial application, because they only require dioxygen as oxidant and also because it can be produced on a large scale [7].

Laccases (phenoloxidases, EC 1.10.3.2) are multicopper oxidases that oxidize substituted phenols using molecular oxygen as the final electron acceptor. The direct action of laccases on lignin is, in principle, restricted to the phenolic units that only represent a small percentage of the total polymer [8], a fact that limits their biotechnological application. However, the discovery that some synthetic compounds can act as electron carriers between the enzyme and the final substrate [9], 1hydroxybenzotriazole (HBT) being among the most efficient ones [10], has expanded the utility of laccases. A number of studies have confirmed the potential of laccasemediator systems for paper pulp delignification [11,12], pitch control [13], polymer modification [14], and other applications in the forest industry [15] and bioethanol production from pretreated lignocellulose [16-18]. Recently, the ability of fungal laccases to remove lignin (when applied in combination with redox mediators) from whole [19,20] and ensiled [21] lignocellulosic biomass, making cellulose accessible to hydrolysis, was reported. Additionally, the use of laccases in bioethanol production has also been reported as a biotechnological tool for the removal of phenolic inhibitors generated during steam explosion of lignocellulosic feedstocks [22], although some recent work also shows that some laccase-derived compounds can affect negatively the enzymatic hydrolysis [23].

A previous work on the laccase-mediator treatment of acid-pretreated wheat straw has been reported [17]. The novelty of the pretreatment described here, based on the use of a fungal laccase from the basidiomycete Pycnoporus cinnabarinus [24] in combination with HBT as mediator [25], is that it was applied directly in the ground wheat straw feedstock (without a previous chemical pretreatment). Additionally, in the present study, the modification of lignin structure in the pretreated lignocellulosic material was analyzed in-depth by two-dimensional nuclear magnetic resonance (2D NMR) spectroscopy of the whole sample at the gel state [26,27]. Besides lignin modification and removal, the effect of the laccase-mediator on the saccharification yield from the pretreated wheat straw feedstock was also assessed.

\section{Material and Methods}

\section{Lignocellulosic feedstock, enzyme and mediator}

Wheat straw (Triticum durum var. Carioca) was harvested from an experimental field in Seville (Spain). Wheat straw samples were air-dried and grounded in an IKA MF10 cutting mill to pass through a 100-mesh screen and then finely milled using a Retsch PM100 planetary mill at $400 \mathrm{rev} \cdot \mathrm{min}^{-1}$ (with $5 \mathrm{~min}$ breaks after every $5 \mathrm{~min}$ of milling) using a $500 \mathrm{~mL}$ agate jar and agate ball bearings $(20 \times 20 \mathrm{~mm})$. The total ball-milling time for the samples was $5 \mathrm{~h}$. The chemical composition of wheat straw feedstock (as \% dry weight) was: glucose, $39.4 \pm 0.7$; xylose, $16.0 \pm 0.3$; arabinose, $3.8 \pm 0.2$; soluble acid lignin, $1.5 \pm 0.1$; Klason lignin, $16.0 \pm 0.3$ ).

The laccase was provided by INRA (Marseille, France) and was obtained from a laccase-hyperproducing strain of the fungus Pycnoporus cinnabarinus (Herpoël et al. 
2000). Its activity was measured as initial velocity during oxidation of $5 \mathrm{mM}$ ABTS from Roche to its cation radical $\left(\varepsilon_{436} 29300 \mathrm{M}^{-1} \cdot \mathrm{cm}^{-1}\right)$ in $0.1 \mathrm{M}$ sodium acetate ( $\left.\mathrm{pH} 5\right)$ at $24^{\circ} \mathrm{C}$. The laccase activity of the enzyme preparation was $102 \mathrm{U} / \mathrm{ml}$ (specific activity $156 \mathrm{U} / \mathrm{mg}$ ). One activity unit (U) was defined as the amount of enzyme transforming 1 $\mu \mathrm{mol}$ of ABTS per min. HBT (1-hydroxybenzotriazole) from Sigma-Aldrich (Steinheim, Germany) was used as mediator.

\section{Laccase-mediator treatments}

The wheat straw samples were treated with the $P$. cinnabarinus laccase in the presence (and absence) of HBT, as mediator (in duplicate experiments). Laccase doses of 13 and $65 \mathrm{U} \cdot \mathrm{g}^{-1}$ were assayed, together with $5 \%, 10 \%$ and $20 \% \mathrm{HBT}$, all referred to straw dry weight. The treatments were carried out in $200-\mathrm{mL}$ pressurized bioreactors (Labomat, Mathis) placed in a thermostatic shaker at $170 \mathrm{rev} \cdot \mathrm{min}^{-1}$ and $50{ }^{\circ} \mathrm{C}$, using $4 \mathrm{~g}$ (dry weight) samples at $6 \%(\mathrm{w}: \mathrm{w})$ solids loading in $50 \mathrm{mM}$ sodium tartrate buffer $(\mathrm{pH} 4)$ under $\mathrm{O}_{2}$ atmosphere ( 2 bars) for $24 \mathrm{~h}$. Additionally, the treatment with laccase $(65 \mathrm{U} \cdot \mathrm{g}$ ${ }^{1}$ ) and HBT (20\%) was also performed in presence of $0.05 \%$ Tween 20, to test the effect of adding a surfactant in both the enzymatic delignification and enzymatic hydrolysis of wheat straw [28]. After the treatment, the samples were filtered through a Büchner funnel and washed with $1 \mathrm{~L}$ of water. In some cases, a subsequent alkaline peroxide extractions step was performed after the enzymatic pretreatment. In this case, enzymatically treated samples at $6 \%(\mathrm{w}: \mathrm{w})$ solids loading were submitted to a peroxidereinforced alkaline extraction using $1 \%$ (w:w) $\mathrm{NaOH}$ and $3 \%$ (w:w) $\mathrm{H}_{2} \mathrm{O}_{2}$ (also with respect to sample dry weight) at $80^{\circ} \mathrm{C}$ for $90 \mathrm{~min}$, followed by water washing [29]. The solids loading for the latter step was achieved by determining the moisture content of an aliquot. Treatments with laccase $\left(65 \mathrm{U} \cdot \mathrm{g}^{-1}\right)$ alone (without mediator) and controls without laccase and mediator, were also performed (followed in both cases by the corresponding alkaline peroxide extraction). A control with mediator alone was not included taking into account the results from previous studies. Duplicate experiments of a representative $\left(65 \mathrm{U} \cdot \mathrm{g}^{-1}\right.$ laccase and $20 \% \mathrm{HBT}$ ) laccase-mediator treatment (including control, laccase alone and laccase-HBT) were performed to estimate the variability in biological replicates (as shown in Table 1 footnote). A one-way analysis of variance (ANOVA) was conducted to compare the effects of the different enzymatic treatments on the lignin removal, and on the releases of glucose and xylose. Post hoc pairwise comparisons, using the Tukey HSD test, were performed in order to determine which means are significantly different from each other. Klason lignin content was estimated (in triplicate measurements) according to T222 om-88 [30]. The data from both biological and technical replicates were averaged. Weight loss (\%) were determined for all the treatments (Table 1) with respect to the control without enzyme-mediator and alkaline extraction: Laccase $\left(65 \mathrm{U} \cdot \mathrm{g}^{-1}\right), 2.3 \%$; Laccase $\left(65 \mathrm{U} \cdot \mathrm{g}^{-1}\right)$-HBT $(20 \%), 6.1 \%$; Control/alkaline peroxide, $0.8 \%$; Laccase $\left(65 \mathrm{U} \cdot \mathrm{g}^{-1}\right) /$ alkaline extraction, $4.8 \%$; Laccase $\left(13 \mathrm{U} \cdot \mathrm{g}^{-1}\right)$-HBT $(10 \%) /$ alkaline extraction, $7.3 \%$; Laccase $\left(65 \mathrm{U} \cdot \mathrm{g}^{-1}\right)$-HBT (5\%)/alkaline extraction, $7.7 \%$; Laccase $\left(65 \mathrm{U} \cdot \mathrm{g}^{-1}\right)$-HBT $(20 \%)$ /alkaline extraction, $13.4 \%$; Laccase $\left(65 \mathrm{U} \cdot \mathrm{g}^{-1}\right)$-HBT $(20 \%) / \mathrm{T} 20 /$ alkaline extraction, $13.5 \%$. The weight loss of control without enzyme-mediator and alkaline extraction with respect to initial wheat straw was $12.7 \%$.

\section{Saccharification of treated wood}


The laccase-pretreated samples were hydrolyzed with a cocktail containing commercial enzymes (from Novozymes, Bagsvaerd) with cellulase (Celluclast $1.5 \mathrm{~L} ; 2$ FPU $\cdot \mathrm{g}^{-1}$ ) and $\beta$-glucosidase (Novozym 188; $6 \mathrm{U} \cdot \mathrm{g}^{-1}$ ) activities, at $1 \%$ solids loading in $3 \mathrm{~mL}$ of 100 $\mathrm{mM}$ sodium citrate ( $\mathrm{pH} 5)$ for $72 \mathrm{~h}$ at $45^{\circ} \mathrm{C}$, in a thermostatic shaker at $170 \mathrm{rev} \cdot \mathrm{min}^{-1}$ (in triplicate experiments). The specific activities of Celluclast $1.5 \mathrm{~L}$ and $\beta$-glucosidase are $700 \mathrm{EGU} / \mathrm{g}$ and $250 \mathrm{CBU} / \mathrm{g}$, respectively.

The different monosaccharides released were determined as alditol acetates [31] by GC. An HP 5890 gas chromatograph (Hewlett-Packard, Hoofddorp, The Netherlands) equipped with a split-splitless injector and a flame ionization detector was used. The injector and detector temperatures were set at 225 and $250{ }^{\circ} \mathrm{C}$, respectively. Samples were injected in the split mode (split ratio 10:1). Helium was used as the carrier gas. The capillary column used was a DB-225 (30 $\mathrm{m} \times 0.25 \mathrm{~mm}$ i.d., $0.15 \mu \mathrm{m}$ film thickness; Agilent J\&W). The oven was temperature-programmed from $220{ }^{\circ} \mathrm{C}$ (held for $5 \mathrm{~min}$ ) to $230{ }^{\circ} \mathrm{C}$ (held for $5 \mathrm{~min}$ ) at $2{ }^{\circ} \mathrm{C} \mathrm{min}^{-1}$. Peaks were quantified by area and glucose and xylose were used as standards to elaborate calibration curves. The data from both biological and technical replicates were averaged.

\section{D NMR spectroscopy}

For gel-state NMR experiments, $\sim 70 \mathrm{mg}$ of finely divided (ball-milled) wheat straw samples were directly transferred into 5-mm NMR tubes, and swelled in $1 \mathrm{~mL}$ of DMSO- $d_{6}$, forming a gel inside the NMR tube $[26,27]$.

HSQC 2D-NMR spectra were acquired at $25^{\circ} \mathrm{C}$ on a Bruker AVANCE III $500 \mathrm{MHz}$ spectrometer fitted with a cryogenically cooled $5 \mathrm{~mm}$ TCI gradient probe with inverse geometry (proton coils closest to the sample). The $2 \mathrm{D}{ }^{13} \mathrm{C}-{ }^{1} \mathrm{H}$ correlation spectra were carried out using an adiabatic HSQC pulse program (Bruker standard pulse sequence 'hsqcetgpsisp2.2'), which enabled a semiquantitative analysis of the different ${ }^{13} \mathrm{C}-{ }^{1} \mathrm{H}$ correlation signals. Spectra were acquired from 10 to 0 ppm $(5000 \mathrm{~Hz})$ in F2 $\left({ }^{1} \mathrm{H}\right)$ using 1000 data points for an acquisition time (AQ) of $100 \mathrm{~ms}$, an interscan delay (D1) of $1 \mathrm{~s}$, and from 200 to $0 \mathrm{ppm}(25,168)$ in $\mathrm{F} 1\left({ }^{13} \mathrm{C}\right)$ using 256 increments of 32 scan, for a total acquisition time of $2 \mathrm{~h} 34 \mathrm{~min}$. The ${ }^{1} J_{\mathrm{CH}}$ used was $145 \mathrm{~Hz}$. Processing used typical matched Gaussian apodization in ${ }^{1} \mathrm{H}$ and a squared cosine bell in ${ }^{13} \mathrm{C}$. The central solvent peak was used as an internal reference $\left(\delta_{\mathrm{C}} / \delta_{\mathrm{H}} 39.5 / 2.49\right)$. The ${ }^{13} \mathrm{C}-{ }^{1} \mathrm{H}$ correlation signals from the aromatic region of the spectrum were used to estimate the content of lignin, $p$-coumaric acid, ferulic acid and tricin (compared with the amorphous polysaccharide content, estimated from the anomeric xylose and glucose signals), and the lignin composition in terms of $\mathrm{G}, \mathrm{S}$ and oxidized $\mathrm{S}\left(\mathrm{S}^{\prime}\right)$ units. Correlations in the aliphatic-oxygenated region were used to estimate the inter-unit linkage and end-unit abundances in lignin. The intensity corrections introduced by the adiabatic pulse program permits to refer the side-chain integrals to the previously obtained number of lignin units.

\section{Results and discussion}

\section{Delignification of wheat straw by laccase-HBT}

Wheat straw lignin is a guaiacyl-rich lignin [32] that usually is reported to be more resistant to degradation than the syringyl type [33]. For this reason, and also based on 
results from previous studies, a high redox potential laccase (from the basidiomycete $P$. cinnabarinus) and mediator (HBT) were selected for wheat straw delignification.

Enzymatic pretreatments using different doses of $P$. cinnabarinus laccase $\left(13 \mathrm{U} \cdot \mathrm{g}^{-1}\right.$ and $\left.65 \mathrm{U} \cdot \mathrm{g}^{-1}\right)$ and HBT (5\%, $10 \%$ and 20\%) were carried out. The selection of these doses was based on previous studies on the pretreatment of another nonwoody feedstock (Elephant grass) [19] with a lignin having also a high proportion of guaiacyl units although not as high as that of wheat straw [32,34]. Additionally, the effect of the combination of the enzymatic treatment with a subsequent alkaline peroxide extraction was studied. The lignin content (as Klason lignin) of wheat straw samples after the pretreatments was determined (Table 1). The effect of oxygen (used in the enzymatic reactions) and alkaline peroxide extraction in wheat straw delignification can be observed by comparing the corresponding controls with the initial straw.

The lignin content of wheat straw samples after the laccase-mediator pretreatment using $P$. cinnabarinus laccase $\left(65 \mathrm{U} \cdot \mathrm{g}^{-1}\right)$ in the presence of HBT $(20 \%)$ decreased about $37 \%$ with respect to the corresponding control (treated under the same conditions except the addition of enzyme and mediator) (Table 1). The pretreatment with laccase alone (in the absence of HBT) only decreased the lignin content by $5 \%$. Similar values of lignin content decrease have been reported after laccase (alone) treatment of several lignocellulosic feedstocks, as steam pretreated giant reed and Northern spruce [35].

The laccase alone is not very efficient for delignification because of its low oxidation potential and for stearic hindrance reasons. The relatively low oxidation potential of laccases only allows them to oxidize phenolic groups in lignin.

Combination of the enzymatic pretreatment with a subsequent alkaline peroxide extraction step (removing partially-degraded lignin) increased wheat straw delignification up to $48 \%$ and $18 \%$ (with respect to lignin content of the control sample) in the pretreatments with laccase-HBT and laccase alone, respectively (Table 1). With the aim of exploring if the enzymatic delignification could be enhanced by the presence of a surfactant, as reported for pulp biobleaching [36], addition of Tween 20 was tested, but only a modest effect on the delignification of wheat straw was observed. When the enzymatic pretreatment (followed by alkaline peroxide extraction) was carried out under the same reaction conditions and dose of laccase, but with lower dose of HBT (5\%), $38 \%$ reduction of lignin content (with respect to the control sample) was attained, and a similar value (37\% delignification) was obtained when both the laccase and mediator doses were reduced to $13 \mathrm{U} \cdot \mathrm{g}^{-1}$ enzyme and $10 \% \mathrm{HBT}$, respectively.

Similar delignification degrees to those above described (with lower laccasemediator doses) were obtained after four sequential laccase-HBT treatments (including four alkaline peroxide extraction steps) of Elephant grass [19]. Interestingly, when the latter pretreatment was applied to eucalypt wood, higher delignification degrees (up to $48 \%$ ) were attained $[19,37,38]$, showing that some woody feedstocks can be competitive for bioethanol production. The better delignification values obtained in the latter studies can be related with the predominance of syringyl lignin units in eucalypt wood with respect to Elephant grass and wheat straw [32,34,39,40]. On the other hand, no decrease in lignin content was obtained by other authors after treating steamexploded wheat straw with $P$. cinnabarinus laccase and HBT [41].

\section{Enzymatic hydrolysis of pretreated wheat straw}

The wheat straw samples treated with laccase alone and in the presence of HBT, and the corresponding controls (and the initial untreated wheat straw) were hydrolyzed (72 h) 
using a cellulase and $\beta$-glucosidase cocktail [19], and the main monosaccharides released (glucose and xylose) were analyzed by GC.

At low cellulase ( 2 filter-paper units [FPU] $\left.\cdot \mathrm{g}^{-1}\right)$ and $\beta$-glucosidase $\left(6 \mathrm{U} \cdot \mathrm{g}^{-1}\right)$ doses, increases in glucose and xylose yields up to $40 \%$ and $47 \%$ (with respect to controls), respectively, were attained in the samples pretreated with $65 \mathrm{U} \cdot \mathrm{g}^{-1}$ of laccase and $20 \%$ mediator (Table 1). Interestingly, in the samples pretreated with laccase alone, 24-25\% increases in glucose and xylose release were produced, although the Klason lignin content was not significantly lowered. The positive effect of laccase (alone) in enzymatic saccharification has been attributed to the binding of laccase to lignin in lignocellulosic substrates that competes with, and consequently reduces the non-specific binding of cellulases to lignin improving saccharification [17], in addition to some delignification effect on the phenolic lignin units. Moreover, a surface analysis of lignocellulose substrate after treatment with Trametes laccase revealed an increase in carboxylic acid residues after laccase treatment, and suggested that this enzymatic modification to lignin may decrease the non-specific adsorption of negatively charged cellulases [16].

On the other hand, increases up to $46 \%$ and $9 \%$ in glucose and $35 \%$ and $0 \%$ in xylose yields, respectively, were produced when the enzymatic pretreatments of laccase-HBT and laccase alone were combined with an alkaline peroxide extraction step (the highest increases being attained with the highest doses of laccase, $65 \mathrm{U} \cdot \mathrm{g}-1$, and HBT, 20\%). Moreover, a similar improvement in saccharification yield was produced after the laccase-mediator treatment alone (without a subsequent alkaline extraction) unlike in a recent study of a laccase-HBT treatment of acid-pretreated wheat straw [17]. In the pretreatment with $13 \mathrm{U} \cdot \mathrm{g}^{-1}$ of laccase, in combination with $10 \%$ mediator (followed by alkaline extraction), the increases in glucose and xylose yields were $24 \%$ and $16 \%$ (with respect to control), respectively (Table 1). Similarly, an increase in glucose and xylose yields up to $29 \%$ and $17 \%$, respectively, was produced using 65 $\mathrm{U} \cdot \mathrm{g}^{-1}$ of laccase, in combination with only $5 \%$ mediator (followed by alkaline extraction). The above glucose release values are higher than those recently reported by other authors in the treatment with laccase-HBT of acid-pretreated wheat straw [17] in which higher laccase doses were used but also higher solids loading in enzymatic hydrolysis. Other authors have reported no improvement in saccharification yields after different laccase-mediator treatments of steam-exploded wheat straw [41]. On the other hand, the saccharification yields shown here after laccase-mediator pretreatment of wheat straw are higher than those reported for other pretreatments of wheat straw like steam explosion [42]. The sugar degradation and generation of inhibitory compounds during steam explosion that affect the hydrolysis can explain the lower saccharification yields attained in steam-exploded wheat straw. Additionally, it should be mentioned the higher solids loading used by these authors that also may affect enzymatic saccharification.

Finally, noteworthy was the improvement in glucose and xylose yields (up to 60\% and $40 \%$, respectively) obtained in the present study when a surfactant (Tween 20) was added during the laccase-HBT pretreatment (Table 1). Since the addition of Tween 20 did not affect the delignification of wheat straw (as shown above) and, in contrast, enhanced the saccharification, its effect may be related with an increase of cellulase action on cellulose [28].

\section{Enzymatic modification of wheat straw lignin (as shown by 2D NMR)}


The modification of lignin structure produced by the enzymatic pretreatments of wheat straw was studied by 2D NMR. With this purpose, the whole wheat straw samples were swelled in deuterated dimethylsufoxide (DMSO- $d_{6}$ ) forming a gel, and analyzed by heteronuclear single-quantum correlation (HSQC) NMR. The main lignin structures identified are shown in Fig. 1, and the different lignin signals assigned on the spectra are listed in Table 2. The HSQC spectra of the different straw samples are provided in Figs. 2-4. The composition of lignin, in terms of $p$-hydroxyphenyl $(H)$, guaiacyl $(G)$ and syringyl (S) units, and the $p$-coumaric acid and ferulic acid contents, together with the relative abundance of the main inter-unit linkages in the different samples, estimated from the NMR signal volume integrals, are shown in Tables 3-4.

Effect of the laccase-mediator treatment

Fig. 2 shows the HSQC spectra of the wheat straw samples after pretreatment with laccase $\left(65 \mathrm{U} \cdot \mathrm{g}^{-1}\right)$ in the presence $(\mathbf{c , f})$ and absence $(\mathbf{b}, \mathbf{e})$ of HBT $(20 \%)$ and the corresponding control (a,d). The aliphatic-oxygenated region of the HSQC spectrum of the control without enzyme (Fig. 2a) shows signals of lignin and carbohydrates, the latter mainly corresponding to amorphous xylan (X), acetylated xylan ( $\left.\mathrm{X}^{\prime}\right)$ and glucan (Gl) units, since crystalline cellulose is nearly "silent" in lignocellulose gel spectra under solution NMR conditions. In this region, signals of methoxyls and side-chains in $\beta$-O-4' alkyl-aryl ether lignin substructures (A), including $\mathrm{C}_{\alpha} / \mathrm{H}_{\alpha}, \mathrm{C}_{\beta} / \mathrm{H}_{\beta}$ and $\mathrm{C}_{\gamma} / \mathrm{H}_{\gamma}$ correlations ( $\mathrm{A}_{\alpha}, \mathrm{A}_{\beta}$ and $\mathrm{A}_{\gamma}$, respectively) were observed. The $\mathrm{C}_{\alpha} / \mathrm{H}_{\alpha}$ and $\mathrm{C}_{\beta} / \mathrm{H}_{\beta}$ correlations gave two different signals corresponding to $\beta-O-4$ ' substructures where the second unit is an $S$ unit or a $G$ unit $\left(A_{\alpha(S)}\right.$ and $A_{\alpha(G)}$, and $A_{\beta(S)}$ and $A_{\beta(G)}$, respectively). The $\mathrm{A}_{\gamma}$ signal overlaps with related signals in lignin and other lignocellulose constituents. Other less prominent signals corresponding to phenylcoumaran (B) and resinol (C) substructures were also observed in the HSQC spectrum. The main signals in the aromatic/unsaturated region of the HSQC spectrum (Fig. 2d) correspond to the benzenic rings and unsaturated side chains of $\mathrm{H}, \mathrm{G}$ and $\mathrm{S}$ lignin units, $p$-coumaric acid (PCA) and ferulic acid (FA). Additionally, several signals corresponding to the flavone tricin $(\mathrm{T})$ recently reported in wheat-straw lignin [32], were observed. The S-lignin units showed a prominent signal for the $\mathrm{C}_{2,6} / \mathrm{H}_{2,6}$ correlation $\left(\mathrm{S}_{2,6}\right)$, while the G-lignin units showed different correlations for $\mathrm{C}_{2} / \mathrm{H}_{2}\left(\mathrm{G}_{2}\right), \mathrm{C}_{5} / \mathrm{H}_{5}\left(\mathrm{G}_{5}\right)$ and $\mathrm{C}_{6} / \mathrm{H}_{6}\left(\mathrm{G}_{6}\right)$. From the integrals of the above signals an $\mathrm{S} / \mathrm{G}$ ratio around 0.4 , and a large predominance of $\beta-O$ 4 ' ether linkages, together with some phenylcoumarans and resinols, were estimated for lignin in wheat straw feedstock, in agreement with previous studies [32]. A low intensity signal corresponding to $\mathrm{C}_{2,6} / \mathrm{H}_{2,6}$ correlation in $\mathrm{H}$ units $\left(\mathrm{H}_{2,6}\right)$ was also observed. On the other hand, the $p$-coumaric acid prominent signals in this region corresponded to the $\mathrm{C}_{2,6} / \mathrm{H}_{2,6}\left(\mathrm{PCA}_{2,6}\right)$ and $\mathrm{C}_{3,5} / \mathrm{H}_{3,5}\left(\mathrm{PCA}_{3,5}\right)$ aromatic correlations, and the $\mathrm{C}_{\alpha} / \mathrm{H}_{\alpha}\left(\mathrm{PCA}_{\alpha}\right)$ and $\mathrm{C}_{\beta} / \mathrm{H}_{\beta}\left(\mathrm{PCA}_{\beta}\right)$ olefinic correlations. Additionally, two signals corresponding to $\mathrm{C}_{2} / \mathrm{H}_{2}$ and $\mathrm{C}_{6} / \mathrm{H}_{6}$ correlations in ferulic acid ( $\mathrm{FA}_{2}$ and $\mathrm{FA}_{6}$, respectively) were also observed, while the other aromatic and olefinic signals of the ferulic acid overlapped with similar signals of $p$-coumaric acid and lignin $\mathrm{G}$ units.

The HSQC spectra of the wheat straw samples after the treatments with the higher laccase-mediator doses showed important differences compared to the control ones. While the carbohydrate signals remained unchanged, most of the lignin (and cinnamic acid) signals were strongly decreased with respect to the initial and control samples (Table 2). The prominent signals of side-chains in $\beta-O-4$ ' lignin substructures (A), present in the control spectrum (Fig. 2a), as well as B and C signals were not observed after the enzymatic treatment (Fig. 2c). On the other hand, the signals of lignin units $(\mathrm{H}$, 
G and S) present in the spectrum of the control sample (Fig. 2d) also disappeared (Fig. 2f), except the very low intensity $S$ signal. Moreover, the signals of cinnamates (PCA and FA) also disappeared whereas, interestingly, the flavonoid structure, tricin, seemed to be more resistant to laccase-mediator treatments (Fig. 2f).

A prominent signal corresponding to $\mathrm{C}_{2,6} / \mathrm{H}_{2,6}$ correlations in $\mathrm{C}_{\alpha}$-oxidized S-lignin units $\left(S_{2,6}^{\prime}\right)$ appeared as a consequence of this treatment. Likewise, new signals, tentatively assigned to oxidized G-lignin units $\left(\mathrm{G}^{\prime}\right)$ appeared in the spectrum. Generation of oxidized lignin structures is congruent with the nature of the lignin biodegradation process, which has been described as an "enzymatic combustion" where fungal oxidoreductases play a central role [43]. It is generally accepted that lignin degradation by white rot fungi and their ligninolytic peroxidases starts by aromatic ring oxidation to a cation radical, but quickly leads to side-chain $\mathrm{C}_{\alpha}-\mathrm{C}_{\beta}$ cleavage causing depolymerization [44]. The same mechanism has been suggested for some laccase reactions mediated by synthetic compounds, e.g. 2,2-azinobis(3-ethylbenzothiazoline-6sulfonate), but the action of laccase-HBT on non-phenolic lignin models is predominantly produced by hydrogen-atom abstraction from the $\mathrm{C}_{\alpha}$ position, followed by alkyl-aryl ether breakdown $[45,46]$. This attack mechanism would result in the increased amount of $\mathrm{C}_{\alpha}$-oxidized lignin units as observed after the laccase-mediator treatment of the wheat straw. Concerning $\mathrm{C}_{\alpha}$-oxidized groups, a higher proportion of $\mathrm{S}$ and $\mathrm{G}$ acid monomers with respect to the aldehyde counterpart has been determined by thermochemolysis in lignins extracted from laccase-mediator treated wheat straw [17].

Remarkably, some lignin modification and removal was also shown by the NMR spectra of the wheat straw treated with laccase alone (Fig. $\mathbf{2 b}, \mathbf{e})$, with a relative decrease of the lignin signals compared to the carbohydrate signals and the initial and control samples (Table 3). Among them, the $C$ signals disappeared, and $A_{\alpha}$ and $A_{\beta}$ and $\mathrm{B}$ signals decreased considerably with respect to the control sample, although the changes were always less intense than those found in the sample treated with laccase and mediator. Concerning the aromatic units, the $\mathrm{G}$ lignin signals decreased slightly and $\mathrm{C}_{\alpha}$-oxidation of $\mathrm{S}$ (and $\mathrm{G}$ ) units was observed to some extent although much less pronounced than in the presence of HBT. The lignin modification observed in the pretreatments with laccase alone could be due to the action of laccase catalyzing the oxidation of the phenolic moiety (less than 20\%) of wheat straw lignin since laccase alone is not able to catalyze the oxidation of non-phenolic lignin units. Reactions of high and low redox potential laccases with lignin models (monomers) have revealed that any laccase reactions are initiated through oxidation of the phenolic hydroxyl group and that laccase cannot directly oxidize the $\alpha$-carbon [47]. This side-chain oxidation to an $\alpha$-carbonyl leads (in reaction with monomers) to further coupling to the 4- or 5position (in guaiacyl-type units). However, if the 5- position is occupied (as in syringyltype groups) the side chain oxidation to an $\alpha$-carbonyl serves as a dead-end reaction with higher oxidation potential or to the coupling to the 1-position with subsequent breakage of the bond producing cleavage of the lignin polymer [47]. On the other hand, the cleavage of the $\mathrm{C}_{\alpha^{-}} \mathrm{C}_{\beta}$ bond catalyzed by laccase has been shown in phenolic lignin model dimers by first oxidizing $\mathrm{C}_{\alpha}$ and by splitting the aryl-alkyl bond [48]. These studies help to explain the lignin degradation observed in the pretreatments with laccase alone. However, it should be taken into account that these reactions occur much easier using model compounds than in polymeric lignin for steric reasons, among others. On the other hand, this lignin modification observed by the action of laccase alone could be also due to the action of natural occurring mediators that can be present in wheat straw.

Noteworthy in the treatment with laccase alone is the preferential decrease of FA signals, with respect to the PCA signals, that would be related to the lower redox 
potential of ferulic acid (due to the presence of an electron-donating substituent on the aromatic ring).

Effect of the alkaline peroxide extraction and laccase-mediator doses

The NMR spectra of the wheat straw treatments followed by an alkaline peroxide extraction are shown in Fig. 3, including control (a,d), laccase alone (b,e) and laccaseHBT (c,f) treatments, and the results from signal integration are provided in Table 4. The spectra of the latter samples (Fig. 3 c,f) were similar to those of samples pretreated under the same conditions but without alkaline peroxide extraction (Fig. 2c,f), although with (slightly) lower intensity aromatic signals (including $\mathrm{C}_{\alpha}$-oxidized lignin units) in agreement with lower lignin content (Table 1). The $\mathrm{S}^{\prime} / \mathrm{S}$ and $\mathrm{G}^{\prime} / \mathrm{G}$ ratios decreased after the alkaline peroxide extraction from 4.4 and 8.5 to 3.3 and 5.5, respectively. During alkaline peroxide extraction, the hydroperoxide anions produced are reported to react with the carbonyl structures existing in lignin resulting in C-C bond cleavage [17], and similar reaction has been reported in alkaline pulping [49].

Differences were also observed between the spectra of laccase pretreated samples without and with an alkaline peroxide extraction. In the latter spectra, a high decrease in $\beta-O-4$ ' side-chains substructures (Fig. 3b) was observed together with the complete disappearance of FA signals and the remarkable decrease of lignin units (Fig. 3e). Finally, some effect was also produced by the alkaline peroxide extraction itself. If we compare the NMR spectra of controls with (Fig. 3a,d) and without (Fig. 2a,d) alkaline peroxide extraction it is evident that $\mathrm{B}$ and $\mathrm{C}$ signals decreased with the alkaline peroxide extraction. Likewise, the intensities of signals of side-chains in $\beta-O-4$ ' lignin, especially those where the second unit is a $G$ unit also decreased. In the aromatic region of the spectrum (Fig. 3d) the most noticeable effect of alkaline peroxide extraction was the decrease in FA. Interestingly, the hemicellulose was not deacetylated (unchanged $\mathrm{X}_{1}^{\prime}, \mathrm{X}_{2}^{\prime}$ and $\mathrm{X}_{3}^{\prime}$ signals) in agreement to the mild conditions of the alkaline extraction used.

Finally, interesting results were obtained when lower laccase and HBT doses were assayed, always followed by an alkaline peroxide extraction, including: i) reduced mediator dose (to only $25 \%$ of the initial) (Fig. $\mathbf{4 b , d}$ ); and ii) reduced both laccase (to $20 \%$ of the initial) and mediator dose (to $50 \%$ of the initial) (Fig. 4a,c). These two treatments seem to be very efficient in degrading/removing lignin (including $\beta-O-4$ ' side-chains and lignin units) similarly to the treatment with higher mediator doses, although the latter showed higher efficacy towards $\mathrm{H}$ lignin units, PCA and tricin. In the three treatments, a preferential degradation of $G$ units with respect to $S$ ones was observed (Table 3). The increase in S/G ratio with the treatment was also revealed in previous studies dealing with laccase-mediator pretreatments of other lignocellulosic feedstocks $[19,37,38]$. On the other hand, in spite of similar lignin removal with both lower doses (Table 1), a higher decrease in S and G lignin units is shown by 2D NMR for the former one that is also correlated with a higher saccharification yield.

\section{Conclusions}

Wheat straw can be delignified by a basidiomycete laccase in the presence of HBT, directly on the ground lignocellulosic material (i.e. without a previous chemical pretreatment) attaining a lignin removal up to $37 \%$. The delignification can be improved up to $48 \%$ if a subsequent alkaline peroxide extraction step is combined with the enzymatic treatment. Although these lignin removal values were attained with high 
mediator doses, noteworthy was the lignin reduction reached (up to $38 \%$ ) in lower doses treatments, which would be more industrially attractive. In all cases assayed, the pretreated wheat straw was hydrolyzed with higher efficiency than the untreated material releasing higher yields of glucose and xylose by using relatively low doses of cellulases. The 2D NMR spectra of whole straw samples (at the gel stage) showed the selective action of laccase-mediator on the lignin moiety, while the polysaccharide signals remained unchanged with respect to the controls. This included the breakdown of inter-unit linkages and removal of lignin $S$ and $G$ units, although tricin remained in the residual lignin. The presence of oxidized $\mathrm{S}$ and $\mathrm{G}$ lignin units in the pretreated wheat straw provides evidence for a $\mathrm{C}_{\alpha}$-oxidation mechanism (and $\beta-O-4$ ' cleavage) of lignin degradation even in the treatments with laccase alone. It should be pointed out that although promising results have been obtained in the present work with the laccasemediator pretreatment of wheat straw, further optimization of the treatment including the increase in solids loading and the decrease of the laccase-mediator doses should be necessary to approach industrial conditions.

\section{Acknowledgements}

This study was funded by the INDOX EU-project (KBBE-2013-7-613549), the LIGNOCELL, LIGNIN and BIORENZYMERY Spanish MICINN (co-financed by FEDER funds) projects (AGL2011-25379, CTQ2014-60764-JIN and AGL2014-53730R) and the CSIC (201440E097) Project. A.P. thanks the Spanish MINECO for a FPI fellowship. A. Lomascolo and E. Record from INRA (Marseille, France) are acknowledged for the $P$. cinnabarinus laccase. The authors thank Dr. Angulo for performing the NMR analyses that were acquired on a Bruker Avance III $500 \mathrm{MHz}$ instrument from the NMR facilities of the General Research Services of the University of Seville (SGI CITIUS).

\section{References}

1. Kim S, Dale BE (2004) Global potential bioethanol production from wasted crops and crop residues. Biomass \& Bioenergy 26:361-375

2. Papa G, Varanasi P, Sun L, Cheng G, Stavila V, Holmes B, Simmons BA, Adani F, Singh S (2012) Exploring the effect of different plant lignin content and composition on ionic liquid pretreatment efficiency and enzymatic saccharification of Eucalyptus globulus L. mutants. Bioresource Technol 117:352359

3. Studer MH, DeMartini JD, Davis MF, Sykes RW, Davison B, Keller M, Tuskan GA, Wyman CE (2011) Lignin content in natural Populus variants affects sugar release. Proc Natl Acad Sci USA 108:6300-6305

4. Li X, Ximenes E, Kim Y, Slininger M, Meilan R, Ladisch M, Chapple C (2010) Lignin monomer composition affects Arabidopsis cell-wall degradability after liquid hot water pretreatment. Biotechnol Biofuels 3:

5. Pareek N, Gillgren T, Jönsson LJ (2013) Adsorption of proteins involved in hydrolysis of lignocellulose on lignins and hemicelluloses. Bioresource Technol online: 
6. Martínez AT, Ruiz-Dueñas FJ, Martínez MJ, del Río JC, Gutiérrez A (2009) Enzymatic delignification of plant cell wall: from nature to mill. Curr Opin Biotechnol 20:348-357

7. Xu F (2005) Applications of oxidoreductases: Recent progress. Industr Biotechnol $1: 38-50$

8. Lai Y-Z (1992) Determination of phenolic hydroxyl groups. In: Lin SY, Dence CW (eds) Methods in lignin chemistry. Berlin: Springer-Verlag, 423-434.

9. Bourbonnais R, Paice MG (1990) Oxidation of non-phenolic substrates. An expanded role for laccase in lignin biodegradation. FEBS Lett 267:99-102

10. Call H-P (1994) Verfahren zur Veränderung, Abbau oder Bleichen von Lignin, ligninhaltigen Materialien oder ähnlichen Stoffen. Patent (International) WO 94/29510:

11. Poppius-Levlin K, Wang W, Tamminen T, Hortling B, Viikari L, Niku-Paavola M-L (1999) Effects of laccase/HBT treatment on pulp and lignin structures. J Pulp Paper Sci 25:90-94

12. Camarero S, García O, Vidal T, Colom J, del Río JC, Gutiérrez A, Gras JM, Monje R, Martínez MJ, Martínez AT (2004) Efficient bleaching of non-wood high-quality paper pulp using laccase-mediator system. Enzyme Microb Technol $35: 113-120$

13. Gutiérrez A, del Río JC, Martínez AT (2009) Microbial and enzymatic control of pitch in the pulp and paper industry. Appl Microbiol Biotechnol 82:1005-1018

14. Prasetyo EN, Kudanga T, Ostergaard L, Rencoret J, Gutiérrez A, del Río JC, Santos JI, Nieto L, Jimenez-Barbero J, Martínez AT et al. (2010) Polymerization of lignosulfonates by the laccase-HBT (1-hydroxybenzotriazole) system improves dispersibility. Bioresource Technol 101:5054-5062

15. Widsten P, Kandelbauer A (2008) Laccase applications in the forest products industry: A review. Enzyme Microb Technol 42:293-307

16. Palonen H, Viikari L (2004) Role of oxidative enzymatic treatments on enzymatic hydrolysis of softwood. Biotechnol Bioeng 86:550-557

17. Heap L, Green A, Brown D, van Dongen B, Turner N (2014) Role of laccase as an enzymatic pretreatment method to improve lignocellulosic saccharification. Catal Sci Technol 4:2251-2259

18. Moilanen U, Kellock M, Vamai A, Andberg M, Viikari L (2014) Mechanisms of laccase-mediator treatments improving the enzymatic hydrolysis of pre-treated spruce. Biotechnol Biofuels 7:

19. Gutiérrez A, Rencoret J, Cadena EM, Rico A, Barth D, del Río JC, Martínez AT (2012) Demonstration of laccase-mediator removal of lignin from wood and nonwood plant feedstocks. Bioresource Technol 119:114-122 
20. Rico A, Rencoret J, del Río JC, Martínez AT, Gutiérrez A (2015) In-depth 2D NMR study of lignin modification during pretreatment of Eucalyptus wood with laccase and mediators. Bioenerg Res 8:211-230

21. Chen Q, Marshall MN, Geib SM, Tien M, Richard TL (2012) Effects of laccase on lignin depolymerization and enzymatic hydrolysis of ensiled corn stover. Bioresource Technol 117:186-192

22. Jurado M, Prieto A, Martínez-Alcalá MA, Martínez AT, Martínez MJ (2009) Laccase detoxification of steam-exploded wheat straw for second generation bioethanol. Bioresource Technol 100:6378-6384

23. Oliva-Taravilla A, Tomás-Pejó E, Demuez M, Gonzalez-Fernandez C, Ballesteros M (2015) Inhibition of Cellulose Enzymatic Hydrolysis by Laccase-Derived Compounds from Phenols. Biotechnol Progr 31:700-706

24. Herpoël I, Moukha S, Lesage-Meessen L, Sigoillot JC, Asther M (2000) Selection of Pycnoporus cinnabarinus strains for laccase production. FEMS Microbiol Lett 183:301-306

25. Bourbonnais R, Paice MG, Freiermuth B, Bodie E, Borneman S (1997) Reactivities of various mediators and laccases with kraft pulp and lignin model compounds. Appl Environ Microbiol 63:4627-4632

26. Rencoret J, Marques G, Gutiérrez A, Nieto L, Santos I, Jiménez-Barbero J, Martínez AT, del Río JC (2009) HSQC-NMR analysis of lignin in woody (Eucalyptus globulus and Picea abies) and non-woody (Agave sisalana) ballmilled plant materials at the gel state. Holzforschung 63:691-698

27. Kim H, Ralph J, Akiyama T (2008) Solution-state 2D NMR of ball-milled plant cell wall gels in DMSO- $d_{6}$. Bioenerg Res 1:56-66

28. Seo DJ, Fujita H, Sakoda A (2011) Structural changes of lignocelluloses by a nonionic surfactant, Tween 20, and their effects on cellulase adsorption and saccharification. Bioresource Technol 102:9605-9612

29. Babot ED, Rico A, Rencoret J, Kalum L, Lund H, Romero J, del Río JC, Martínez AT, Gutiérrez A (2011) Towards industrially feasible delignification and pitch removal by treating paper pulp with Myceliophthora thermophila laccase and a phenolic mediator. Bioresource Technol 102:6717-6722

30. Tappi (2006) 2006-2007 TAPPI Test Methods. Norcoss, GA 30092, USA: TAPPI Press

31. Selvendran RR, March JF, Ring SG (1979) Determination of Aldoses and UronicAcid Content of Vegetable Fiber. Anal Biochem 96:282-292

32. del Río JC, Rencoret J, Prinsen P, Martínez AT, Ralph J, Gutiérrez A (2012) Structural characterization of wheat straw lignin as revealed by analytical pyrolysis, 2D-NMR, and reductive cleavage methods. J Agric Food Chem 60:5922-5935 
33. Hatakka A, Hammel KE (2010) Fungal biodegradation of lignocelluloses. In: Hofrichter M (ed) The Mycota. Industrial applications. Volume 10. Berlin: Springer-Verlag, 319-340.

34. del Río JC, Prinsen P, Rencoret J, Nieto L, Jiménez-Barbero J, Ralph J, Martínez AT, Gutiérrez A (2012) Structural characterization of the lignin in the cortex and pith of Elephant grass (Pennisetum purpureum) stems. J Agric Food Chem 60:3619-3634

35. Moilanen U, Kellock M, Galkin S, Viikari L (2011) The laccase-catalyzed modification of lignin for enzymatic hydrolysis. Enzyme Microb Technol 49:492498

36. Ehara K, Tsutsumi Y, Nishida T Role of Tween 80 in biobleaching of unbleached hardwood kraft pulp with manganese peroxidase. J Wood Sci 46:137-142

37. Rico A, Rencoret J, del Río JC, Martínez AT, Gutiérrez A (2014) In-depth 2D NMR study of lignin modification during pretreatment of Eucalyptus wood with laccase and mediators. Bioenerg Res 8:211-230

38. Rico A, Rencoret J, del Río JC, Martínez AT, Gutiérrez A (2014) Pretreatment with laccase and a phenolic mediator degrades lignin and enhances saccharification of Eucalyptus feedstock. Biotechnol Biofuels 7:6

39. Prinsen P, Gutiérrez A, Rencoret J, Nieto L, Jiménez-Barbero J, Burnet A, PetitConil M, Colodette JL, Martínez AT, del Río JC (2012) Morphological characteristics and composition of lipophilic extractives and lignin in Brazilian woods from different eucalypt hybrids. Ind Crops Prod 36:572-583

40. Rencoret J, Marques G, Gutiérrez A, Ibarra D, Li J, Gellerstedt G, Santos JI, Jiménez-Barbero J, Martínez AT, del Río JC (2008) Structural characterization of milled wood lignin from different eucalypt species. Holzforschung 62:514-526

41. Moreno AD, Ibarra D, Alvira P, Tomás-Pejó E, Ballesteros M (2015) Exploring laccase and mediators behavior during saccharification and fermentation of steamexploded wheat straw for bioethanol production. Journal of Chemical Technology $\&$ Biotechnologyn/a

42. Alvira P, Negro MJ, Ballesteros I, González A, Ballesteros M (2016) Steam explosion for wheat straw pretreatment for sugars production. Bioethanol 2:66-75

43. Kirk TK, Farrell RL (1987) Enzymatic "combustion": The microbial degradation of lignin. Annu Rev Microbiol 41:465-505

44. Ruiz-Dueñas FJ, Martínez AT (2009) Microbial degradation of lignin: How a bulky recalcitrant polymer is efficiently recycled in nature and how we can take advantage of this. Microbial Biotechnol 2:164-177

45. Kawai S, Nakagawa M, Ohashi H (2002) Degradation mechanisms of a nonphenolic $\beta$-O-4 lignin model dimer by Trametes versicolor laccase in the presence of 1-hydroxybenzotriazole. Enzyme Microb Technol 30:482-489 
46. Cantarella G, Galli C, Gentili P. (2003) Free radical versus electron-transfer routes of oxidation of hydrocarbons by laccase-mediator systems. Catalytic and stoichiometric procedures. J Mol Catal B-Enzym 22:135-144

47. Areskogh D, Li J, Nousiainen P, Gellerstedt G, Sipila J, Henriksson G (2010) Oxidative polymerisation of models for phenolic lignin end-groups by laccase. Holzforschung 64:21-34

48. Eriksson K-EL, Blanchette RA, Ander P (1990) Microbial and enzymatic degradation of wood components. Berlin: Springer-Verlag.

49. Gierer J, Ljunggren S (1979) Reactions of lignins during sulfate pulping.16. Kinetics of the cleavage of $\beta$-aryl ether linkages in structures containing carbonyl groups. Svensk Papperstidning-Nordisk Cellulosa 82:71-81 
Table 1 Lignin content and monosaccharide release (\% sample weight) by cellulase hydrolysis of wheat straw samples

\begin{tabular}{llll}
\hline Wheat straw samples & Lignin & Glucose & Xylose \\
\hline $\begin{array}{l}\text { Initial wheat straw } \\
\text { - Laccase-mediator: }\end{array}$ & $16.0 \pm 0.3$ & $21.6 \pm 0.2$ & $6.9 \pm 0.1$ \\
Control & $15.6^{\mathrm{a}} \pm 0.2$ & $24.1^{\mathrm{a}} \pm 0.0$ & $7.3^{\mathrm{a}} \pm 0.4$ \\
Laccase $\left(65 \mathrm{U} \cdot \mathrm{g}^{-1}\right)$ & $15.0^{\mathrm{a}} \pm 0.1$ & $29.0^{\mathrm{b}} \pm 0.1$ & $9.4^{\mathrm{b}} \pm 0.1$ \\
Laccase $\left(65 \mathrm{U} \cdot \mathrm{g}^{-1}\right)$ )-HBT $(20 \%)$ & $9.8^{\mathrm{b}} \pm 0.3$ & $33.6^{\mathrm{c}} \pm 0.2$ & $11.2^{\mathrm{c}} \pm 0.2$ \\
- Laccase-mediator/alkaline peroxide: & & & \\
Control & $14.8^{\mathrm{a}} \pm 0.2$ & $28.4^{\mathrm{a}} \pm 0.4$ & $9.8^{\mathrm{a}} \pm 0.3$ \\
Laccase $\left(65 \mathrm{U} \cdot \mathrm{g}^{-1}\right)$ & $12.1^{\mathrm{b}} \pm 0.3$ & $31.1^{\mathrm{b}} \pm 0.3$ & $9.8^{\mathrm{a}} \pm 0.2$ \\
Laccase $\left(13 \mathrm{U} \cdot \mathrm{g}^{-1}\right)-\mathrm{HBT}(10 \%)$ & $9.4^{\mathrm{c}} \pm 0.1$ & $35.1^{\mathrm{c}} \pm 0.5$ & $11.4^{\mathrm{b}} \pm 0.6$ \\
Laccase $\left(65 \mathrm{U} \cdot \mathrm{g}^{-1}\right)-\mathrm{HBT}(5 \%)$ & $9.2^{\mathrm{c}} \pm 0.4$ & $36.5^{\mathrm{d}} \pm 0.3$ & $11.5^{\mathrm{b}} \pm 0.6$ \\
Laccase $\left(65 \mathrm{U} \cdot \mathrm{g}^{-1}\right)-\mathrm{HBT}(20 \%)$ & $7.7^{\mathrm{d}} \pm 0.2$ & $41.5^{\mathrm{e}} \pm 0.7$ & $13.3^{\mathrm{c}} \pm 0.2$ \\
Laccase $\left(65 \mathrm{U} \cdot \mathrm{g}^{-1}\right)-\mathrm{HBT}(20 \%) / \mathrm{T} 20$ & $7.5^{\mathrm{d}} \pm 0.2$ & $45.5^{\mathrm{f}} \pm 0.6$ & $13.7^{\mathrm{c}} \pm 0.0$ \\
\hline
\end{tabular}

Lignin content (as Klason lignin, corrected for ash) and monosaccharides from cellulase hydrolysis of wheat straw samples treated with: i) P. cinnabarinus laccase (13 and $65 \mathrm{U} \cdot \mathrm{g}^{-}$ $\left.{ }^{1}\right)$ and HBT mediator (10\% and $\left.20 \%\right)$; ii) the same previous enzymatic treatment (i) followed by an alkaline peroxide extraction including a treatment in presence of Tween 20 (T20), and (ii) compared with a control without enzyme, a treatment with laccase alone, and the initial wheat straw sample. Biological duplicates for a representative laccasemediator treatment (including $65 \mathrm{U} \cdot \mathrm{g}^{-1}$ laccase and 20\% HBT) were separately analyzed showing that the $95 \%$ confidence intervals of the biological duplicates are smaller than the differences found between the control, laccase alone and laccase-HBT treatments (data not shown). In the table, means \pm S.D. from technical triplicates of experiments representative for the different treatments are provided. Superscript letters next to the means, obtained by Tukey test, show whether or not the results from different treatments (shown in each column) are significantly different from each other, at the 0.05 level (means with the same letters are not significantly different, whereas means followed by different letters are significantly different). 
Table 2 Assignments of lignin ${ }^{13} \mathrm{C}-{ }^{1} \mathrm{H}$ correlation signals in the 2D HSQC spectra of wheat straw samples

\begin{tabular}{|c|c|c|}
\hline Label & $\delta_{\mathrm{C}} / \boldsymbol{\delta}_{\mathrm{H}}(\mathbf{p p m})$ & Assignment \\
\hline$\overline{\mathrm{B}_{\beta}}$ & $53.1 / 3.41$ & $\mathrm{C}_{\beta} / \mathrm{H}_{\beta}$ in phenylcoumaran substructures $(\mathbf{B})$ \\
\hline $\mathrm{C}_{\beta}$ & $53.5 / 3.06$ & $\mathrm{C}_{\beta} / \mathrm{H}_{\beta}$ in $\beta-\beta^{\prime}$ resinol substructures $(\mathbf{C})$ \\
\hline$-\mathrm{OCH}_{3}$ & $55.5 / 3.72$ & $\mathrm{C} / \mathrm{H}$ in methoxyls \\
\hline $\mathrm{A}_{\gamma}$ & $59.6 / 3.37$ and 3.71 & $\mathrm{C}_{\gamma} / \mathrm{H}_{\gamma}$ in $\gamma$-hydroxylated $\beta-O-4^{\prime}$ substructures (A) \\
\hline $\mathrm{I}_{\gamma}$ & $61.5 / 4.09$ & $\mathrm{C}_{\gamma} / \mathrm{H}_{\gamma}$ in cinnamyl alcohol end-groups (I) \\
\hline $\mathrm{X}_{5}$ & $62.9 / 3.16$ and 3.87 & $\mathrm{C}_{5} / \mathrm{H}_{5}$ in xylopyranose units \\
\hline $\mathrm{A}_{\alpha(\mathrm{G})}$ & $71.1 / 4.71$ & $\mathrm{C}_{\alpha} / \mathrm{H}_{\alpha}$ in $\beta-O-4^{\prime}$ substructures (A) linked to a G-unit \\
\hline $\mathrm{C}_{\gamma}$ & $71.2 / 4.17$ & $\mathrm{C}_{\gamma} / \mathrm{H}_{\gamma}$ in $\beta-\beta^{\prime}$ resinol substructures $(\mathbf{C})$ \\
\hline $\mathrm{A}_{\alpha(\mathrm{S})}$ & $71.5 / 4.81$ & $\mathrm{C}_{\alpha} / \mathrm{H}_{\alpha}$ in $\beta-O-4^{\prime}$ substructures (A) linked to a $\mathrm{S}$-unit \\
\hline $\mathrm{X}_{2}$ & $72.5 / 3.03$ & $\mathrm{C}_{2} / \mathrm{H}_{2}$ in xylopyranose units \\
\hline $\mathrm{X}_{2}^{\prime}$ & $73.1 / 4.49$ & $\mathrm{C}_{2} / \mathrm{H}_{2}$ in $2-O$-acetylated xylopyranose units \\
\hline$X_{3}$ & $73.8 / 3.23$ & $\mathrm{C}_{3} / \mathrm{H}_{3}$ in xylopyranose units \\
\hline $\mathrm{X}_{3}^{\prime}$ & $74.7 / 4.79$ & $\mathrm{C}_{3} / \mathrm{H}_{3}$ in $3-O$-acetylated xylopyranose units \\
\hline $\mathrm{X}_{4}$ & $75.2 / 3.50$ & $\mathrm{C}_{4} / \mathrm{H}_{4}$ in xylopyranose units \\
\hline $\mathrm{A}_{\beta(\mathrm{G})}$ & $83.5 / 4.35$ & $\mathrm{C}_{\beta} / \mathrm{H}_{\beta}$ in $\beta-O-4^{\prime}$ substructures linked (A) to a $\mathrm{G}$ unit \\
\hline $\mathrm{C}_{\alpha}$ & $84.7 / 4.63$ & $\mathrm{C}_{\alpha} / \mathrm{H}_{\alpha}$ in $\beta-\beta^{\prime}$ resinol substructures $(\mathbf{C})$ \\
\hline $\mathrm{A}_{\beta(\mathrm{S})}$ & $85.9 / 4.05$ & $\mathrm{C}_{\beta} / \mathrm{H}_{\beta}$ in $\beta-O-4^{\prime}$ substructures linked (A) to a $\mathrm{S}$ unit \\
\hline $\mathrm{B}_{\alpha}$ & $86.8 / 5.42$ & $\mathrm{C}_{\alpha} / \mathrm{H}_{\alpha}$ in phenylcoumaran substructures $(\mathbf{B})$ \\
\hline $\mathrm{T}_{8}$ & $94.0 / 6.56$ & $\mathrm{C}_{8} / \mathrm{H}_{8}$ in tricin units $(\mathbf{T})$ \\
\hline $\mathrm{T}_{6}$ & $98.8 / 6.20$ & $\mathrm{C}_{6} / \mathrm{H}_{6}$ in tricin units $(\mathbf{T})$ \\
\hline$X_{1}^{\prime}$ & $99.3 / 4.48$ & $\mathrm{C}_{1} / \mathrm{H}_{1}$ in $3-O$-acetylated xylopyranose units \\
\hline $\mathrm{X}_{1} / \mathrm{X}_{1}^{\prime}$ & $101.5 / 4.26$ & $\mathrm{C}_{1} / \mathrm{H}_{1}$ in xylopyranose units \\
\hline $\mathrm{Gl}_{1}$ & $102.9 / 4.16$ & $\mathrm{C}_{1} / \mathrm{H}_{1}$ in glucopyranose units \\
\hline $\mathrm{S}_{2,6}$ & $103.8 / 6.69$ & $\mathrm{C}_{2} / \mathrm{H}_{2}$ and $\mathrm{C}_{6} / \mathrm{H}_{6}$ in etherified syringyl units $(\mathbf{S})$ \\
\hline $\mathrm{T}_{2,6}$ & $103.9 / 7.28$ & $\mathrm{C}_{2^{\prime}} / \mathrm{H}_{2^{\prime}}$ and $\mathrm{C}_{6} / \mathrm{H}_{6^{\prime}}$ in tricin units $(\mathbf{T})$ \\
\hline $\mathrm{T}_{3}$ & $104.6 / 7.02$ & $\mathrm{C}_{3} / \mathrm{H}_{3}$ in tricin units $(\mathbf{T})$ \\
\hline $\mathrm{S}_{2,6}^{\prime}$ & $106.1 / 7.29,106.2 / 7.18$ & $\mathrm{C}_{2} / \mathrm{H}_{2}$ and $\mathrm{C}_{6} / \mathrm{H}_{6}$ in $\alpha$-oxidized syringyl units $\left(\mathbf{S}^{\prime}\right)$ \\
\hline $\mathrm{G}_{2}$ & $110.7 / 6.96$ & $\mathrm{C}_{2} / \mathrm{H}_{2}$ in guaiacyl units $(\mathbf{G})$ \\
\hline $\mathrm{G}_{2}^{\prime}$ & $110.8 / 7.38$ & $\mathrm{C}_{2} / \mathrm{H}_{2}$ in $\alpha$-oxidized guaiacyl units $\left(\mathbf{G}^{\prime}\right)$ \\
\hline $\mathrm{FA}_{2}$ & $110.9 / 7.33$ & $\mathrm{C}_{2} / \mathrm{H}_{2}$ in ferulate $(\mathbf{F A})$ \\
\hline $\mathrm{PCA}_{\beta} / \mathrm{FA}_{\beta}$ & $113.5 / 6.29$ & $\mathrm{C}_{\beta} / \mathrm{H}_{\beta}$ in $p$-coumarate (PCA) and ferulate $(\mathbf{F A})$ \\
\hline $\mathrm{H}_{3,5}$ & $113.6 / 6.64$ & $\mathrm{C}_{3} / \mathrm{H}_{3}$ and $\mathrm{C}_{5} / \mathrm{H}_{5}$ in $p$-hydroxyphenyl units $(\mathbf{H})$ \\
\hline $\mathrm{FA}_{5}$ & $114.1 / 6.77$ & $\mathrm{C}_{5} / \mathrm{H}_{5}$ in ferulate $(\mathbf{F A})$ \\
\hline $\mathrm{G}_{5} / \mathrm{G}_{6}$ & $114.9 / 6.78,6.94$ and $118.8 / 6.77$ & $\mathrm{C}_{5} / \mathrm{H}_{5}$ and $\mathrm{C}_{6} / \mathrm{H}_{6}$ in guaiacyl units $(\mathbf{G})$ \\
\hline $\mathrm{G}_{5}^{\prime}$ & $115.0 / 6.73$ & $\mathrm{C}_{5} / \mathrm{H}_{5}$ in $\alpha$-oxidized guaiacyl units $\left(\mathbf{G}^{\prime}\right)$ \\
\hline $\mathrm{PCA}_{3,5}$ & $115.3 / 6.76$ & $\mathrm{C}_{3} / \mathrm{H}_{3}$ and $\mathrm{C}_{5} / \mathrm{H}_{5}$ in $p$-coumarate $(\mathbf{P C A})$ \\
\hline $\mathrm{FA}_{6}$ & $123.2 / 7.10$ & $\mathrm{C}_{6} / \mathrm{H}_{6}$ in ferulate $(\mathbf{F A})$ \\
\hline $\mathrm{H}_{2,6}$ & $127.6 / 7.14$ & $\mathrm{C}_{2} / \mathrm{H}_{2}$ and $\mathrm{C}_{6} / \mathrm{H}_{6}$ in $p$-hydroxyphenyl units $(\mathbf{H})$ \\
\hline
\end{tabular}


$\mathrm{PCA}_{2,6} \quad 130.0 / 7.48$

$\mathrm{C}_{2} / \mathrm{H}_{2}$ and $\mathrm{C}_{6} / \mathrm{H}_{6}$ in $p$-coumarate (PCA)

$\mathrm{PCA}_{\alpha} / \mathrm{FA}_{\alpha}$ 145.0/7.58

$\mathrm{C}_{\alpha} / \mathrm{H}_{\alpha}$ in $p$-coumarate (PCA) and ferulate (FA)

From Figs. 2-4 HSQC spectra. See Fig. 1 for chemical structures. 
Table 3 NMR analysis of straw treated with laccase-HBT and controls (parentheses refer to total lignin $)^{1}$

\begin{tabular}{|c|c|c|c|c|}
\hline & Initial & Control & Laccase & Laccase-HBT \\
\hline \multicolumn{5}{|l|}{ - Sample composition ${ }^{2}$ : } \\
\hline Syringyl lignin units $(\mathbf{S})$ & $5.8(30)$ & $7.7(31)$ & $5.5(30)$ & $0.5(7)$ \\
\hline $\mathrm{C}_{\alpha}$-oxidized $\mathrm{S}$ units $\left(\mathbf{S}^{\prime}\right)$ & $0(0)$ & $0(0)$ & $0.4(2)$ & $2.2(32)$ \\
\hline Guaiacyl lignin units $(\mathbf{G})$ & $12.6(63)$ & $15.2(63)$ & $11.1(60)$ & $0.4(6)$ \\
\hline $\mathrm{C}_{\alpha}$-oxidized $\mathrm{G}$ units $\left(\mathbf{G}^{\prime}\right)$ & $0(0)$ & $0(0)$ & $0.5(3)$ & $3.4(51)$ \\
\hline$p$-Hydroxyphenyl units (H) & $1.5(7)$ & $1.5(6)$ & $0.9(5)$ & $0.3(4)$ \\
\hline Total lignin & $19.9(100)$ & $24.4(100)$ & $18.4(100)$ & $6.7(100)$ \\
\hline Tricin $(\mathbf{T})$ & $3.6(18)$ & 4.7 (19) & 3.4 (19) & $3.5(52)$ \\
\hline$p$-Coumaric acid (PCA) & $1.3(6)$ & $1.8(7)$ & $1.5(8)$ & $0(0)$ \\
\hline Ferulic acid (FA) & $3.4(17)$ & $3.8(15)$ & $2.0(11)$ & $0(0)$ \\
\hline Total aromatics & 28.1 & 34.6 & 25.3 & 10.2 \\
\hline Sugar units & 71.9 & 65.4 & 74.7 & 89.8 \\
\hline Total & 100 & 100 & 100 & 100 \\
\hline Lignin $S / G$ ratio & 0.46 & 0.50 & 0.51 & 0.70 \\
\hline \multicolumn{5}{|l|}{ - Side chains and end groups ${ }^{3}$ : } \\
\hline$\beta-O-4^{\prime}$ ethers $(\mathbf{A})$ & $80(61)$ & $82(62)$ & $88(59)$ & 0 \\
\hline Phenylcoumarans (B) & $8(6)$ & $9(7)$ & $4(3)$ & 0 \\
\hline Resinols $(\mathbf{C})$ & $9(7)$ & $7(5)$ & $4(3)$ & 0 \\
\hline Cinnamyl end groups (I) & $3(3)$ & $3(2)$ & $4(3)$ & 0 \\
\hline Total & $100(77)$ & $100(76)$ & $100(68)$ & 0 \\
\hline
\end{tabular}

${ }^{\mathrm{T}}$ Milled wheat straw was treated with laccase $\left(65 \mathrm{U} \cdot \mathrm{g}^{-1}\right)$ in combination with HBT $(20 \%)$ and laccase alone, and compared with control treatment (without enzyme) and initial material (spectrum not shown) using HSQC NMR (Fig. 2).

${ }^{2}$ Sample composition provides the molar amount of normal $(\mathrm{S}, \mathrm{G}$ and $\mathrm{H})$ and $\mathrm{C}_{\alpha}$-oxidized ( $\mathrm{S}$ ' and $\mathrm{G}^{\prime}$ ) lignin units, $\mathrm{S} / \mathrm{G}$ ratio, tricin $(\mathrm{T}), p$-coumaric acid (PCA) and ferulic acid (FA) from integration of aromatic signals, and sugar units from integration of anomeric-carbon signals, in the HSQC spectra (parentheses, values referred to $\mathrm{H}+\mathrm{G}+\mathrm{G}^{\prime}+\mathrm{S}+\mathrm{S}^{\prime}$ )

${ }^{3}$ The percentages of lignin side chains forming different substructure (A-C) and cinnamyl alcohol end groups are provided from integration of aliphatic signals in the HSQC spectra (parentheses, values referred to $\mathrm{H}+\mathrm{G}+\mathrm{G}^{\prime}+\mathrm{S}+\mathrm{S}^{\prime}$ ) 
Table 4 NMR analysis after laccase-HBT (different doses) treatment followed by alkaline-extraction (parentheses refer to total lignin $)^{1}$

\begin{tabular}{|c|c|c|c|c|c|}
\hline & Control & Laccase & $\begin{array}{l}\text { Lac13- } \\
\text { HBT10 }\end{array}$ & $\begin{array}{l}\text { Lac65- } \\
\text { HBT5 }\end{array}$ & $\begin{array}{l}\text { Lac65- } \\
\text { HBT20 }\end{array}$ \\
\hline \multicolumn{6}{|l|}{ - Sample composition ${ }^{2}$} \\
\hline Syringyl lignin units $(\mathbf{S})$ & $4.8(28)$ & $3.3(30)$ & $1.3(24)$ & $0.2(8)$ & $0.3(10)$ \\
\hline $\mathrm{C}_{\alpha}$-oxidized S units $\left(\mathbf{S}^{\prime}\right)$ & 0 & $0.3(3)$ & $1.0(19)$ & $0.6(29)$ & $1.0(38)$ \\
\hline Guaiacyl lignin units $(\mathbf{G})$ & $11.6(68)$ & $6.5(58)$ & $1.5(28)$ & $0.7(37)$ & $0.2(6)$ \\
\hline $\mathrm{C}_{\alpha}$-oxidized $\mathrm{G}$ units $\left(\mathbf{G}^{\prime}\right)$ & 0 & $0.3(3)$ & $1.1(20)$ & 0 & $1.1(39)$ \\
\hline p-Hydroxyphenyl units $(\mathbf{H})$ & $0.8(5)$ & $0.8(7)$ & $0.4(8)$ & $0.5(26)$ & $0.2(7)$ \\
\hline Total lignin & $17.2(100)$ & $11.1(100)$ & $5.3(100)$ & $1.9(100)$ & $2.7(100)$ \\
\hline Tricin $(\mathbf{T})$ & $3.1(18)$ & $2.7(25)$ & $2.0(38)$ & $3.0(154)$ & $1.4(50)$ \\
\hline$p$-Coumaric acid (PCA) & $1.4(8)$ & $0.8(7)$ & $0.3(6)$ & $0.3(13)$ & 0 \\
\hline Ferulic acid (FA) & $2.6(15)$ & $0.3(3)$ & 0 & 0 & 0 \\
\hline Total aromatics & 24.2 & 15.0 & 7.7 & 5.1 & 4.1 \\
\hline Sugar units & 75.8 & 85.1 & 92.3 & 94.9 & 96.0 \\
\hline Total & 100 & 100 & 100 & 100 & 100 \\
\hline Lignin $S / G$ ratio & 0.41 & 0.53 & 0.89 & 1.02 & 1.05 \\
\hline \multicolumn{6}{|l|}{ - Side chains and end groups ${ }^{3}$ : } \\
\hline$\beta-O-4^{\prime}$ ethers $(\mathbf{A})$ & $76(59)$ & $91(59)$ & $100(16)$ & $29(12)$ & 0 \\
\hline Phenylcoumarans (B) & $6(5)$ & 0 & 0 & 0 & 0 \\
\hline Resinols $(\mathbf{C})$ & $10(8)$ & 0 & 0 & 0 & 0 \\
\hline Cinnamyl end groups (I) & $8(6)$ & $9(6)$ & 0 & $71(30)$ & 0 \\
\hline Total & $100(78)$ & $100(65)$ & $100(16)$ & $100(42)$ & 0 \\
\hline
\end{tabular}

${ }^{\mathrm{I}}$ Milled wheat straw was treated with 13 or $65 \mathrm{U} \cdot \mathrm{g}^{-1}$ of laccase (Lac13 and Lac65) in combination with 5,10 or $20 \%$ HBT (HBT5, HBT10 and HBT20, respectively), and compared with laccase alone and with a control without enzyme (followed in all cases by an extraction with alkaline peroxide) using HSQC NMR (Figs. 2,3).

${ }^{2,3}$ See Table 2 footnotes 2 and 3. 


\section{LEGENDS FOR FIGURES}

Fig. 1 Main lignin structures identified in the wheat straw samples analyzed by HSQC NMR (Figs. 2-4). A) $\beta-O-4$ ' ether (including a second S or G unit); B) phenylcoumaran; C) resinol; T) tricin; PCA) $p$-coumaric acid; FA) ferulic acid (esterified with hemicellulose sugars); I) cinnamyl alcohol end-group; H) $p$-hydroxyphenyl unit; G) guaiacyl unit; S) syringyl unit; $\mathbf{G}^{\prime}$ ) $\mathrm{C}_{\alpha}$-oxidized $\mathrm{G}$ unit; $\mathbf{S}^{\prime}$ ) $\mathrm{C}_{\alpha}$-oxidized $\mathrm{S}$ unit; (R in $\mathrm{G}^{\prime}$ and $\mathrm{S}^{\prime}$ can be a hydroxyl in carboxylic acids, or a lignin side-chain in ketones).

Fig. 2 HSQC NMR spectra of wheat straw after laccase-mediator treatment (without a subsequent alkaline peroxide extraction). Expanded aliphatic oxygenated $\left(\delta_{\mathrm{H}}-\delta_{\mathrm{C}}, 2.5-6.0\right.$ and 50-110 ppm; top) and aromatic $\left(\delta_{\mathrm{H}^{-}} \delta_{\mathrm{C}}, 5.8-8.2\right.$ and 90-150 ppm; bottom) regions of the HSQC NMR spectra of wheat straw treated with $P$. cinnabarinus laccase-HBT: a,d) Control without enzyme; b,e) $65 \mathrm{U} \cdot \mathrm{g}^{-1}$ enzyme; and c,f) $65 \mathrm{U} \cdot \mathrm{g}^{-1}$ enzyme and $20 \%$ HBT. See Table 2 for lignin signal assignment, Fig. 1 for the main lignin structures identified, and Table 3 for quantification of these lignin structures. Carbohydrate signals are also observed mainly corresponding to $\mathrm{C}_{1}-\mathrm{C}_{5}$ in normal $\left(\mathrm{X}_{1}-\mathrm{X}_{5}\right)$ and acetylated xylan units $\left(\mathrm{X}_{1}{ }_{1}-\mathrm{X}_{5}{ }_{5}\right.$ ) (an anomeric glucose signal was also identified, $\mathrm{G}_{1}$ ) (unassigned signals in gray, including signals from the enzyme and the mediator).

Fig. 3 HSQC NMR spectra of wheat straw after laccase-mediator treatment (higher doses) and alkaline peroxide extraction. Expanded aliphatic oxygenated (top) and aromatic (bottom) regions of the HSQC NMR spectra of wheat straw samples after treatment with laccase-HBT followed by an alkaline peroxide extraction: a,d) Control without enzyme; b,e) $65 \mathrm{U} \cdot \mathrm{g}^{-1}$ enzyme; and c,f) $65 \mathrm{U} \cdot \mathrm{g}^{-1}$ enzyme and $20 \%$ HBT. See Fig. 2 legend for additional information.

Fig. 4 HSQC NMR spectra of wheat straw after laccase-mediator treatment (lower doses) and alkaline peroxide extraction. Expanded aliphatic oxygenated (top) and aromatic (bottom) regions of the HSQC NMR spectra of wheat straw samples after treatment with laccase-HBT followed by an alkaline peroxide extraction: a,b) $13 \mathrm{U} \cdot \mathrm{g}^{-1}$ enzyme and 10\% HBT; and c,d) $65 \mathrm{U} \cdot \mathrm{g}^{-1}$ enzyme and 5\% HBT. See Fig. 2 legend for additional information. 


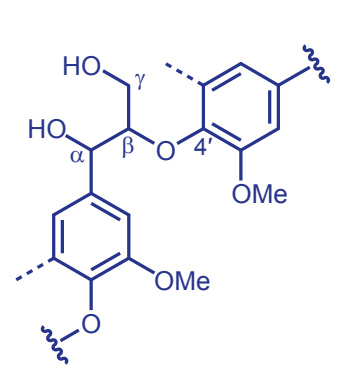

A

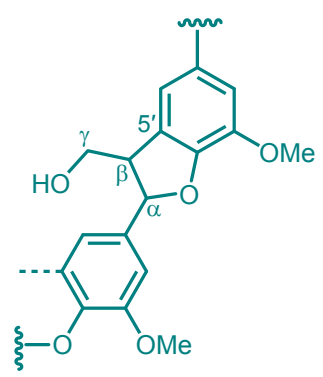

B

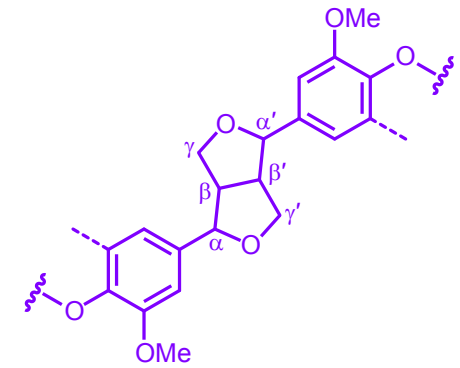

C<smiles>CCOc1c(OC)cc(-c2cc(=O)c3c(O)cc(O)cc3o2)cc1OC</smiles><smiles>CCOc1ccc(C=NC(=O)OC)cc1OC</smiles><smiles>CCOC(=O)/C=C/c1ccc(O)cc1</smiles>

PCA<smiles>CCC(O)C(C)O</smiles><smiles>CCOc1c(C)cc(C(=O)P)cc1OC</smiles><smiles>CCOc1cc(C(O)CC)cc(OC)c1OCC</smiles><smiles>[2H]C(=O)c1cc(OC)c(OC)c(OC[Si])c1OC</smiles> 

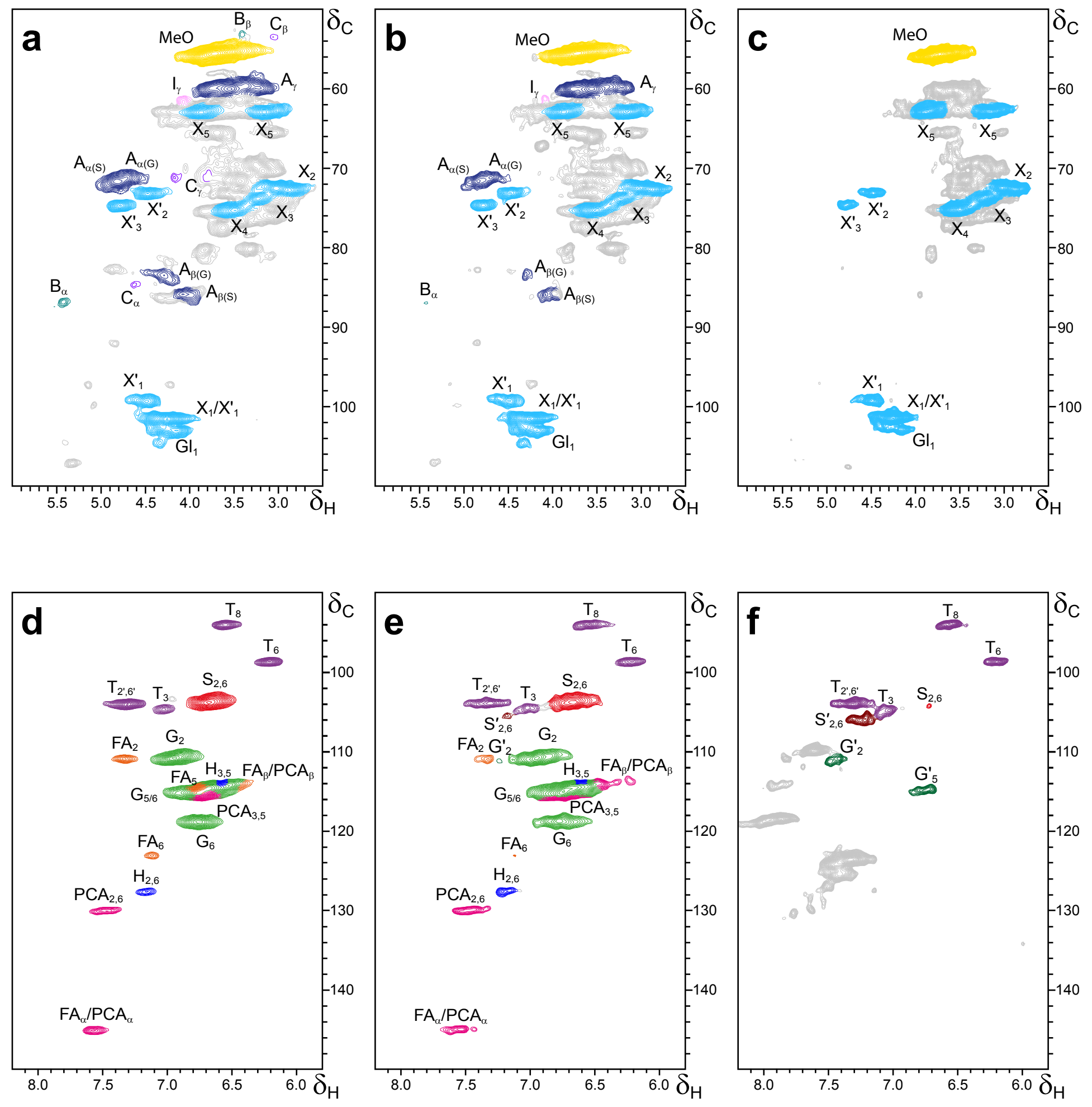

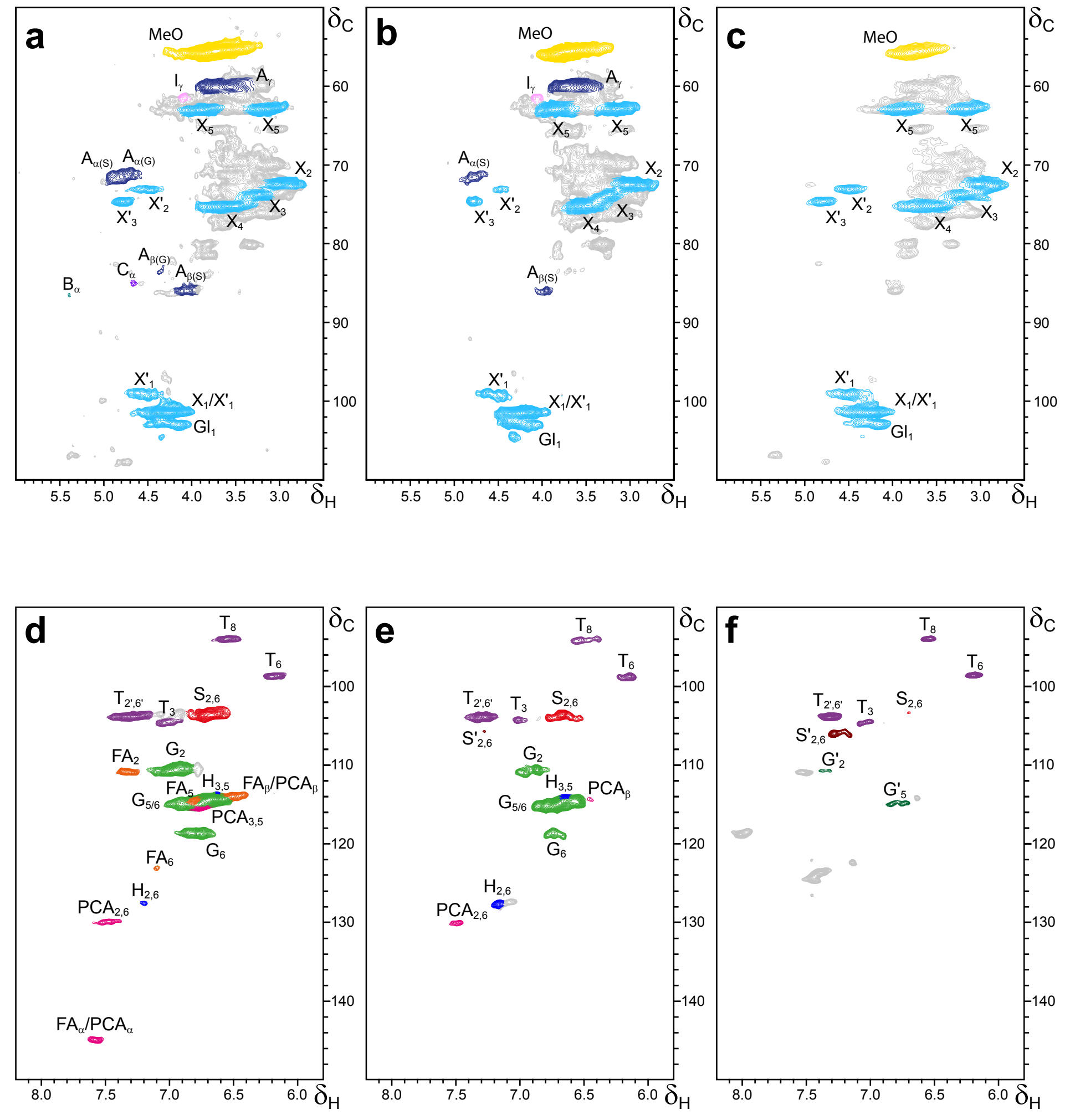

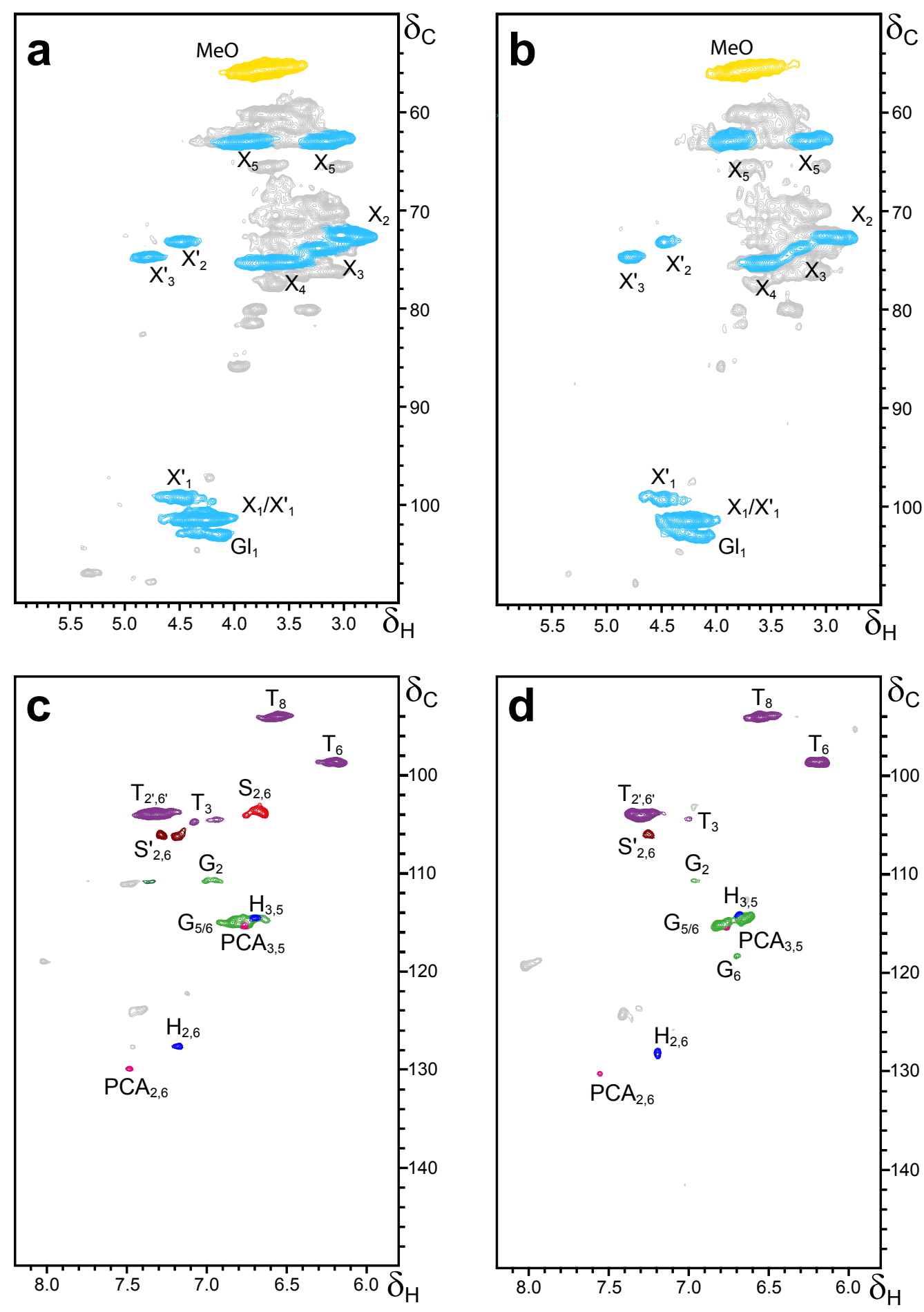